\title{
SISTEM REKOMENDASI TEMPAT WISATA DI KOTA MALANG DENGAN METODE FUZZY BERBASIS WEB
}

\author{
Elys Sugiharto $^{1 *}$, Istiadi ${ }^{2}$, Indra Dharma Wijaya ${ }^{3}$ \\ ${ }^{1,2}$ Program Studi Teknik Informatika, Fakultas Teknik, Universitas Widyagama Malang \\ ${ }^{3}$ Jurusan Teknologi Informasi, Politeknik Negeri Malang \\ *Email Korespondensi: sugihartoelys@gmail.com
}

Submitted : 2 Oktober 2020; Revision : 19 November 2020; Accepted : 8 Februari 2021

\begin{abstract}
ABSTRAK
Wisatawan yang ingin berwisata ke Kota Malang seringkali merasa bingung dalam memutuskan untuk mengunjungi tempat wisata yang cocok bagi mereka. Selain itu, tidak terdapat sarana informasi yang dapat diakses sehingga wisatawan kesulitan dalam mencari informasi terkini mengenai wisata di Kota Malang. Oleh sebab itu, dibuatlah sebuah sistem rekomendasi tempat wisata di Kota Malang menggunakan Fuzzy Sugeno berbasis web. Metode Fuzzy Sugeno merupakan proses pengambilan keputusan perangkingan yang akan menyeleksi alternatif terbaik dari sejumlah alternatif dan penilaian lebih tepat karena didasarkan pada toleransi terhadap data-data yang tidak tepat. Bahasa pemrograman yang digunakan adalah PHP dengan basis data MySQL. Parameter yang digunakan pada proses fuzzifikasi adalah fasilitas dengan 6 fungsi keanggotaan, yaitu: toilet (T), makanan (A), mushola (U), oleh-oleh $(\mathrm{O})$, taman hiburan $(\mathrm{H})$ dan spot foto $(\mathrm{S})$. Output fuzzy yang dihasilkan berupa rating bintang 1 sampai dengan bintang 5 . Metode pengujian sistem yang digunakan adalah user testing dengan melibatkan 5 responden. Berdasarkan hasil pengujian, sistem rekomendasi tempat wisata di Kota Malang dapat diterima oleh user dan sudah sesuai dengan kebutuhan user yang dibuktikan dengan perolehan persentase pada pilihan Sangat Setuju (SS) sebesar 60\%.
\end{abstract}

Kata kunci : Sistem Rekomendasi, Tempat Wisata, Logika Fuzzy, Kota Malang

\section{ABSTRACT}

Tourists who want to travel to Malang City feel confused in deciding to visit a tourist spot that is suitable for them. Also, there are no information facilities that can be accessed so that tourists have difficulty finding updated information about tourism in Malang City. Therefore, a system of recommendation for tourist attractions in Malang was made using web-based Fuzzy Sugeno. The Fuzzy Sugeno method is a decision-making process that will select the best alternative from consideration and a correct decision because it is based on incorrect data. The programming language used is PHP with MySQL database. The parameters used in the fuzzification process are facilities with 6 functions, namely: toilets $(T)$, food $(A)$, prayer rooms $(U)$, souvenirs $(O)$, amusement parks $(H)$ and photo spots $(S)$. The resulting fuzzy output is in the form of a 1 to a 5-star rating. The testing system method used is user testing involving 5 respondents. Based on the test results, the recommendation system for tourist attractions in Malang City can be accepted by the user and is following the user's needs as evidenced by the acquisition of the proportion of the Strongly Agree (SS) option of $60 \%$.

Keywords : Recommendation System, Tourist Attractions, Fuzzy Logic, Malang City

\section{PENDAHULUAN}

Kota Malang merupakan salah satu kota wisata yang terletak di Jawa Timur dengan keaneka ragaman budaya sebagai aset kekayaan daerah yang potensial dan harus dikembangkan seoptimal mungkin. Kota Malang memiliki berbagai tempat objek wisata budaya dan sejarah yang menarik untuk dikunjungi. Wisatawan yang ingin berwisata ke Kota Malang seringkali merasa bingung dalam memutuskan untuk mengunjungi tempat wisata yang cocok bagi mereka. Selain itu, tidak terdapat sarana informasi yang dapat 
diakses sehingga wisatawan kesulitan dalam mencari informasi terkini mengenai tempat wisata khususnya di Kota Malang. Publikasi informasi yang dilakukan oleh pemerintah belum bisa menjangkau wisatawan secara luas karena media informasi yang digunakan hanya terbatas pada media cetak, di antaranya: brosur, spanduk dan poster. Oleh karena itu, diperlukan adanya sebuah sistem rekomendasi tempat wisata berbasis web yang dapat menampung dan menyajikan informasi mengenai jenis tempat wisata di Kota Malang (Firmansyah, Santoso and Dewi, 2017; Prawira dan Wardani, 2018).

Sistem rekomendasi merupakan model aplikasi dari hasil observasi terhadap keadaan dan keinginan pelanggan. Oleh karena itu, sistem rekomendasi memerlukan model rekomendasi yang tepat agar yang direkomendasikan sesuai dengan keinginan pelanggan, serta mempermudah pelanggan mengambil keputusan yang tepat dalam menentukan produk yang akan digunakannya (Arief, 2016).

Berdasarkan masalah yang telah diuraikan, diangkatlah sebuah penelitian mengenai sistem rekomendasi tempat wisata di Kota Malang menggunakan Fuzzy Sugeno berbasis web. Keunggulan metode fuzzy adalah proses pengambilan keputusan perangkingan yang akan menyeleksi alternatif terbaik dari sejumlah alternatif dan penilaian lebih tepat karena didasarkan pada toleransi terhadap data-data yang tidak tepat. Logika fuzzy mampu memodelkan fungsi-fungsi nonlinear yang kompleks dan mempunyai daya guna lebih baik daripada metode lain (Kusumadewi dan Purnomo, 2010). Kata fuzzy merupakan kata sifat yang berarti kabur atau tidak jelas. Fuzziness atau kekaburan atau ketidakjelasan selalu meliputi keseharian manusia. Logika fuzzy adalah suatu cara yang tepat untuk memetakan ruang input ke dalam suatu ruang output. Konsep ini diperkenalkan dan dipublikasikan pertama kali oleh Lotfi A. Zadeh, seorang professor dari University of California di Berkeley pada tahun 1965. Logika fuzzy menggunakan ungkapan bahasa untuk menggambarkan nilai variabel. Logika fuzzy bekerja dengan menggunakan derajat keanggotaan dari sebuah nilai yang kemudian digunakan untuk menentukan hasil yang ingin dicapai berdasarkan atas spesifikasi yang telah ditentukan. Ada beberapa hal yang perlu diketahui dalam memahami sistem fuzzy, yaitu: variabel fuzzy, himpunan fuzzy, semesta pembicaraan dan domain himpunan fuzzy.

Penggunaan logika fuzzy sangat memudahkan dan mengefisienkan penggunaan sistem rekomendasi yang diimplementasikan ke dalam bahasa mesin. Hal ini disebabkan logika fuzzy mampu menjembatani bahasa mesin yang serba presisi dengan bahasa manusia yang cenderung tidak presisi yaitu dengan menekankan pada makna atau arti (significance). Konsep matematis yang mendasari penalaran fuzzy sangat sederhana dan mudah dimengerti, memiliki toleransi data-data yang tidak tepat, membangun dan mengaplikasikan pengalaman-pengalaman secara langsung tanpa harus melalui proses konvensional (Arief, 2016).

Pada penelitian (Firmansyah, Santoso dan Dewi, 2017) melakukan penelitian terkait pembangunan sistem rekomendasi tempat wisata di Kota Malang menggunakan metode floyd-warshall untuk proses penentuan jalur terdekat dari maps dan metode fuzzy untuk proses penentuan wisata yang akan dikunjungi. Kemudian, (Busthomy dan Sultoni, 2016) melakukan penelitian terkait pembangunan sistem pendukung keputusan pemilihan objek wisata di Kabupaten Pasuruan menggunakan metode fuzzy tahani untuk memberikan rekomendasi pemilihan objek wisata di Kabupaten Pasuruan sesuai dengan kriteria yang dipilih. Sedangkan pada penelitian ini, peneliti melakukan penelitian terkait pembangunan sistem rekomendasi tempat wisata, khususnya di Kota Malang, menggunakan metode fuzzy sugeno berdasarkan 6 variabel, yaitu toilet (T), makanan (A), mushola (U), oleh-oleh (O), taman hiburan $(\mathrm{H})$ dan spot foto $(\mathrm{S})$.

Referensi penelitian yang pertama dilakukan oleh (Firmansyah, Santoso dan Dewi, 2017) membahas mengenai Sistem Rekomendasi Tempat Wisata di Kota Malang menggunakan Metode Hybrid Fuzzy-Floyd Warshall. Tujuan dari penelitian tersebut adalah membantu wisatawan dalam memutuskan untuk mengunjungi tempat wisata yang mana yang cocok bagi mereka. Hasil dari penelitian tersebut yaitu list tempat rekomendasi

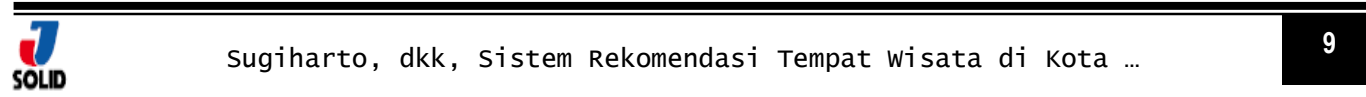


wisata berdasarkan harga tiket, jarak, dan waktu. Proses penentuan jalur terdekat dari maps akan dibantu oleh metode floyd-warshall dan proses penentuan wisata yang akan dikunjungi menggunakan metode fuzzy. Sedangkan pada penelitian yang dilakukan oleh peneliti, Sistem Rekomendasi Tempat Wisata di Kota Malang dikembangkan menggunakan metode Fuzzy Sugeno. Metode Fuzzy Sugeno mempunyai langkah integrasi fuzzy yang kompleks. Selain itu, variabel yang digunakan pada penelitian ini juga lebih banyak dibandingkan referensi penelitian pertama, yaitu sebanyak 6 variabel (toilet, makanan, mushola, oleh-oleh, taman hiburan, spot foto). Oleh sebab itu, hasil tempat wisata di Kota Malang yang direkomendasikan juga semakin akurat sesuai dengan keinginan atau kriteria user.

Referensi penelitian yang kedua dilakukan oleh (Busthomy dan Sultoni, 2016) membahas mengenai Sistem Pendukung Keputusan Untuk Pemilihan Objek Wisata Di Kabupaten Pasuruan Dengan Menggunakan Metode Fuzzy. Tujuan dari penelitian tersebut adalah memberi kemudahan pada calon pengunjung wisata untuk memilih objek wisata di Kabupaten Pasuruan yang sesuai kriteria. Hasil dari penelitian tersebut yaitu sistem pendukung keputusan untuk pemilihan objek wisata di Kabupaten Pasuruan. Metode Fuzzy berfungsi untuk memberikan rekomendasi pemilihan objek wisata di Kabupaten Pasuruan sesuai dengan kriteria yang dipilih. Sedangkan pada penelitian yang dilakukan oleh peneliti, Sistem Rekomendasi Tempat Wisata yang dikembangkan berfokus pada wilayah Kota Malang dan sekitarnya. Selain itu, pada penelitian ini Sistem Rekomendasi Tempat Wisata di Kota Malang yang sudah selesai dibangun selanjutnya diuji untuk mengetahui tingkat penerimaan user. Sehingga peneliti dapat mengetahui apakah Sistem Rekomendasi Tempat Wisata di Kota Malang sudah dapat diterima oleh user atau belum dan sudah sesuai dengan kebutuhan user atau belum.

Sistem rekomendasi merupakan model aplikasi dari hasil observasi terhadap keadaan dan keinginan pelanggan. Oleh karena itu, sistem rekomendasi memerlukan model rekomendasi yang tepat agar yang direkomendasikan sesuai dengan keinginan pelanggan, serta mempermudah pelanggan mengambil keputusan yang tepat dalam menentukan produk yang akan digunakannya (Welling dan Thomson, 2003; Abdul, 2008; Kadir, 2008; Hayati, 2011; Putra, Jonemaro dan Arwani, 2018).

\section{METODE}

\section{Proses Logika Fuzzy}

Prosedur penelitian yang diterapkan pada penelitian terkait pembuatan sistem rekomendasi tempat wisata di Kota Malang dapat dimulai dengan pembentukan himpunan fuzzy (fuzzifikasi) dalam penelitian ini adalah fasilitas. Di dalam parameter fasilitas terdapat 6 variabel yang terdiri dari:

$\mathrm{T}=$ Toilet (Kurang, Sedang, Bagus)

A $=$ Makanan (Kurang, Sedang, Bagus)

$\mathrm{U}=$ Mushola (Kurang, Sedang, Bagus)

$\mathrm{O}=$ Oleh-oleh (Kurang, Sedang, Bagus)

$\mathrm{H}=$ Taman Hiburan (Kurang, Sedang, Bagus)

$\mathrm{S}=$ Spot Foto (Kurang, Sedang, Bagus)

$\mathrm{Z}=$ Output fuzzy (Bintang 1, 2, 3, 4, 5)

Pada penelitian ini, input parameter fasilitas yang dihasilkan berbentuk himpunan bilangan tegas/nyata (crisp). Sehingga diperlukan proses fuzzifikasi untuk mengubah masukan tegas/nyata menjadi nilai fuzzy dalam interval antara 0 sampai dengan 1 pada himpunan fuzzy. Sebelum proses fuzzifikasi, peneliti menentukan fungsi keanggotaan (membership function) terlebih dahulu. Fungsi keanggotaan adalah suatu kurva yang menunjukkan pemetaan titik-titik input data ke dalam nilai keanggotaannya (sering juga disebut dengan derajat keanggotaan) yang memiliki interval antara 0 sampai 1 . Salah satu cara yang dapat digunakan untuk mendapatkan nilai keanggotaan adalah melalui pendekatan fungsi. 
Fungsi keanggotaan toilet (T), makanan (A), mushola (U), oleh-oleh $(\mathrm{O})$, taman hiburan (H) dan spot foto (S) dibagi menjadi 3 himpunan fuzzy, yaitu: 'kurang', 'sedang', dan 'bagus'. Nilai maksimal yang dimiliki himpunan 'kurang' adalah 30, himpunan 'sedang' adalah 60, dan himpunan 'tinggi' adalah 100. Grafik fungsi keanggotaan setiap fasilitas dapat dilihat pada Gambar 1.

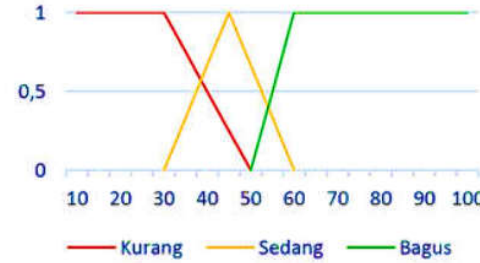

(a)

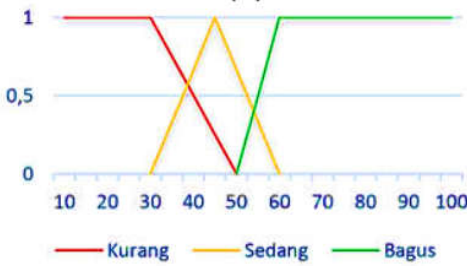

(c)

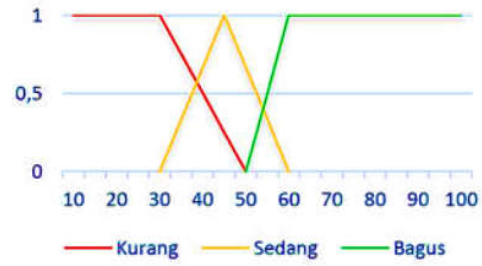

(e)

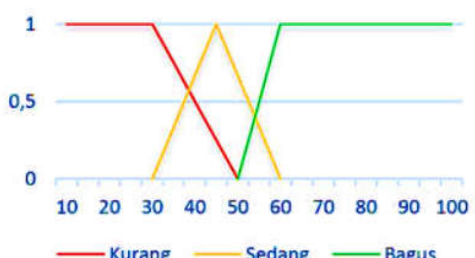

(b)

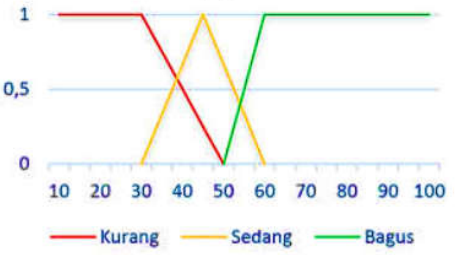

(d)

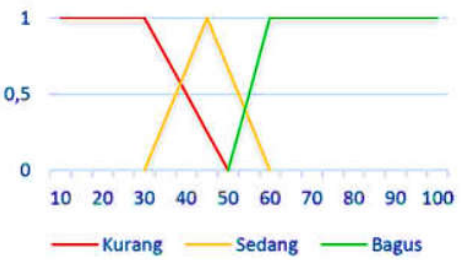

(f)

Gambar 1. Fungsi Keanggotaan untuk (a) Toilet (T), (b) Makanan (A), (c) Mushola (U), (d) Oleh-Oleh (O), (e) Taman Hiburan (H), dan (f) Spot Foto (S)

Setelah proses pembuatan fungsi keanggotaan dan fuzzifikasi, langkah selanjutnya adalah pembentukan fuzzy rule. Pada penelitian ini, nilai diagram fuzzy output (Z) ditentukan secara manual dengan nilai range 0 sampai dengan 100 yang dibagi menjadi 5 himpunan variabel output yaitu bintang 1, bintang 2, bintang 3, bintang 4, dan bintang 5 . Diagram fuzzy output (Z) dapat dilihat pada Gambar 2.

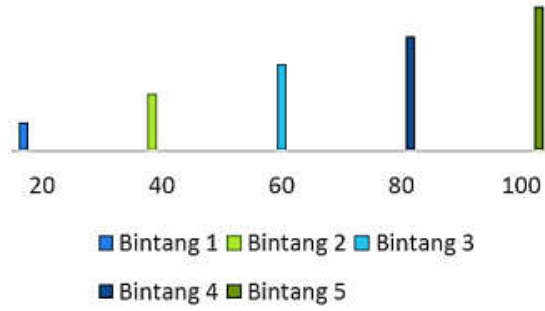

Gambar 2. Grafik Fuzzy Output (Z)

Langkah selanjutnya melakukan pembentukan rule base system. Rule base system didapatkan dari 6 variabel (toilet, makanan, mushola, oleh-oleh, taman hiburan, spot foto) yang masing-masing memiliki 3 himpunan fuzzy (kurang, sedang, bagus). Oleh sebab itu, terdapat 36 atau 729 basis pengetahuan (rule base). Setelah proses pembentukan fuzzy rule, dan langkah selanjutnya adalah pembentukan final output. Proses pencarian nilai output fuzzy dilakukan menggunakan fungsi MIN metode Sugeno. Fungsi MIN ini digunakan 
untuk mendapatkan nilai $\alpha$ predikat hasil implikasi dengan teknik memotong output himpunan fuzzy sesuai dengan derajat keanggotaan terkecil. Dalam metode Sugeno, output fuzzy berupa persamaan linear dengan rumus weight average. Kemudian, masing-masing nilai $\alpha$ predikat digunakan untuk menghitung output masing-masing rule (z).

\section{Use Case Diagram}

Penggambaran use case diagram dari sistem rekomendasi tempat wisata di Kota Malang dengan metode fuzzy berbasis web yang dapat dilihat pada Gambar 3.

\section{Activity Diagram}

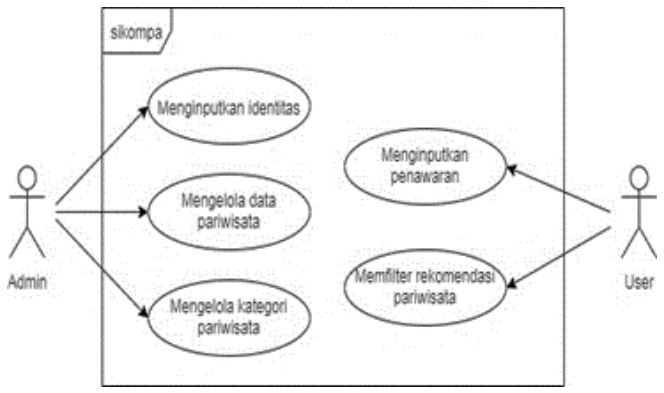

Gambar 3. Use Case Diagram

Penggambaran activity diagram dari sistem rekomendasi tempat wisata di Kota Malang dengan metode fuzzy berbasis web yang dapat dilihat pada Gambar 4.

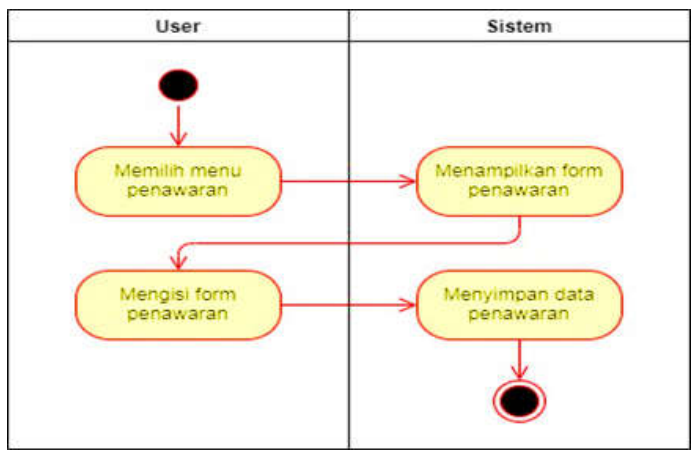

Gambar 4. Activity Diagram Menginputkan Penawaran

\section{Sequence Diagram}

Penggambaran sequence diagram dari sistem rekomendasi tempat wisata di Kota Malang dengan metode fuzzy berbasis web yang dapat dilihat pada Gambar 5.

\section{HASIL DAN PEMBAHASAN}

Tampilan antarmuka dari sistem rekomendasi tempat wisata di Kota Malang yang dapat dilihat pada Gambar 6 dan 7. Pengujian sistem dilakukan dengan cara melakukan user testing. User yang dipilih pada tahap pengujian sistem sebanyak 5 orang dengan kriteria mempunyai hobi traveling, sehingga membutuhkan sistem yang dapat merekomendasikan sebuah tempat wisata di suatu kota. Setelah melakukan uji coba, user diminta untuk mengisi kuesioner yang telah disiapkan. Hasil rekapitulasi pengujian user testing dapat dilihat pada Tabel 1. Respon user disediakan 4 respon, yaitu sangat tidak setuju (STS), tidak setuju (TS), setuju (S), dan sangat setuju (SS) mengenahi tampilan web rekomendasi wisata di Kota Malang. 


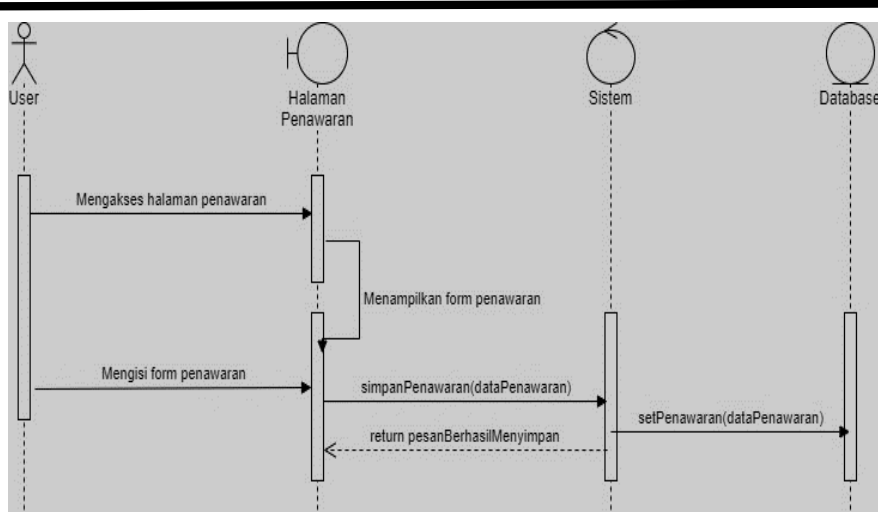

Gambar 5. Sequence Diagram Menginputkan Penawaran

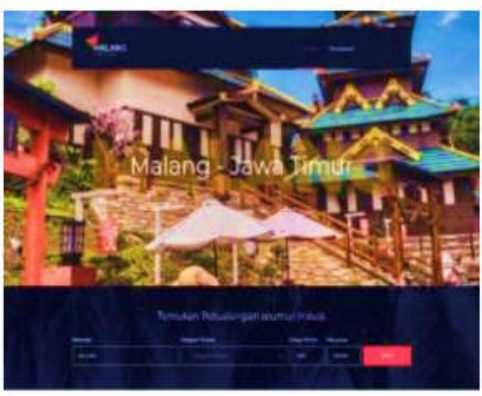

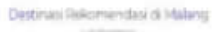
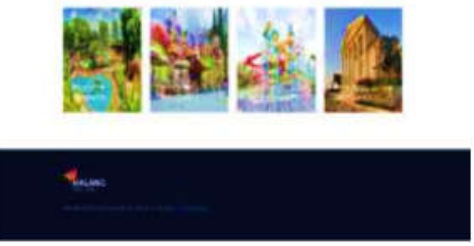

Gambar 6. Tampilan Halaman Home
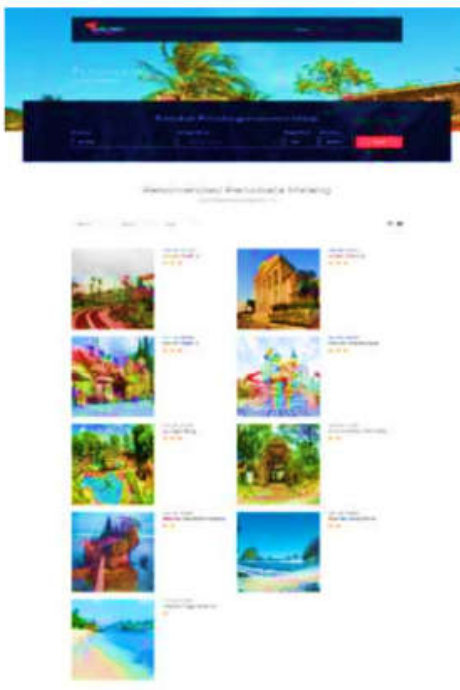

Gambar 7. Tampilan Halaman Penawaran 
Tabel 1. Hasil Ujicoba User Terhadap Layanan Web

\begin{tabular}{|c|c|c|c|c|c|}
\hline \multirow{2}{*}{ No. } & \multirow{2}{*}{ Pertanyaan } & \multicolumn{4}{|c|}{ Respon } \\
\hline & & STS & TS & $\mathbf{S}$ & SS \\
\hline 1. & $\begin{array}{l}\text { Apakah tampilan dari sistem } \\
\text { rekomendasi tempat wisata di } \\
\text { Kota Malang menarik? }\end{array}$ & $\overline{0}$ & 0 & 4 & $T$ \\
\hline 2. & $\begin{array}{l}\text { Apakah tata letak fitur dari } \\
\text { sistem rekomendasi tempat } \\
\text { wisata di Kota Malang } \\
\text { mudah dipahami? }\end{array}$ & $\overline{0}$ & 0 & 3 & 2 \\
\hline 3. & $\begin{array}{l}\text { Apakah fungsi setiap menu } \\
\text { dari sistem rekomendasi } \\
\text { tempat wisata di Kota } \\
\text { Malang mudah dipahami? }\end{array}$ & 0 & 2 & 2 & 1 \\
\hline 4. & $\begin{array}{l}\text { Apakah sistem rekomendasi } \\
\text { tempat wisata di Kota } \\
\text { Malang dapat melakukan } \\
\text { filter tempat wisata } \\
\text { berdasarkan harga atau } \\
\text { rating? }\end{array}$ & 0 & 0 & 0 & 5 \\
\hline 5. & $\begin{array}{l}\text { Apakah sistem rekomendasi } \\
\text { tempat wisata di Kota } \\
\text { Malang dapat memastikan } \\
\text { bahwa tempat wisata yang } \\
\text { ditampilkan beraneka ragam? }\end{array}$ & 0 & 0 & 0 & 5 \\
\hline 6. & $\begin{array}{l}\text { Apakah sistem rekomendasi } \\
\text { tempat wisata di Kota } \\
\text { Malang dapat memberikan } \\
\text { detail informasi sebuah } \\
\text { tempat wisata? }\end{array}$ & 0 & 1 & 1 & 3 \\
\hline 7. & $\begin{array}{l}\text { Apakah sistem rekomendasi } \\
\text { tempat wisata di Kota } \\
\text { Malang membantu dalam } \\
\text { mencari tempat wisata? }\end{array}$ & 0 & 0 & 1 & 4 \\
\hline 8. & $\begin{array}{l}\text { Apakah sistem rekomendasi } \\
\text { tempat wisata di Kota } \\
\text { Malang dapat menampilkan } \\
\text { hasil rekomendasi tempat } \\
\text { wisata sesuai dengan harapan } \\
\text { pengguna? }\end{array}$ & 0 & 1 & 4 & $\overline{0}$ \\
\hline 9. & $\begin{array}{l}\text { Apakah sistem rekomendasi } \\
\text { tempat wisata di Kota } \\
\text { Malang dapat dijadikan } \\
\text { acuan dalam mencari tempat } \\
\text { wisata? }\end{array}$ & 0 & 0 & 0 & 5 \\
\hline 10. & $\begin{array}{l}\text { Apakah sistem rekomendasi } \\
\text { tempat wisata di Kota } \\
\text { Malang dapat } \\
\text { diimplementasikan pada } \\
\text { kehidupan sehari-hari? } \\
\end{array}$ & 0 & 0 & 1 & 4 \\
\hline & TOTAL & 0 & 4 & 16 & 30 \\
\hline
\end{tabular}

Berdasarkan hasil analisis, Sistem Rekomendasi Tempat Wisata di Kota Malang dengan Metode Fuzzy Berbasis Web dapat diterima oleh user dan sudah sesuai dengan kebutuhan user yang dibuktikan dengan perolehan persentase pada pilihan Sangat Setuju (SS) sebesar 60\%.

\section{DAMPAK DAN MANFAAT}

Dengan dibuatnya web untuk wisatawan yang ingin berwisata ke Kota Malang dapat memutuskan untuk mengunjungi tempat wisata yang sesuai. Wisatawan mendapatkan informasi yang dapat diakses dengan mudah sehingga wisatawan tidak merasa kesulitan dalam mencari informasi terkini dan mengenai wisata di Malang Raya. 


\section{KESIMPULAN}

Berdasarkan hasil penelitian terkait implementasi sistem rekomendasi tempat wisata di Malang Raya, maka dapat diambil kesimpulan bahwa berdasarkan perhitungan yang telah dilakukan, maka perhitungan logika fuzzy menggunakan Metode Sugeno dapat membantu user dalam menemukan rekomendasi tempat wisata yang sesuai berdasarkan kategori wisata, dan harga yang diinginkan. Berdasarkan pengujian yang telah dilakukan, Sistem Rekomendasi Tempat Wisata di Malang Raya dengan Metode Fuzzy Berbasis Web dapat diterima oleh user dan sudah sesuai dengan kebutuhan user yang dibuktikan dengan perolehan persentase pada pilihan Sangat Setuju (SS) sebesar 60\%.

\section{UCAPAN TERIMA KASIH}

Ucapan terimakasih disampaikan kepada pihak-pihak yang telah sangat membantu terselesaikannya penelitian ini. Terutama kedua orang tua, semua dosen Teknik Informatika, Universitas Widyagama, dan teman-teman Teknik Informatika semuanya.

\section{REFERENSI}

Abdul, K. (2008) 'Dasar Pemrograman Web Dinamis Menggunakan PHP', Yogyakarta: Andi Offset.

Arief, A. (2016) 'Rancang Bangun Sistem Rekomendasi Pariwisata Mobile Advertising Menggunakan Metode Hybrid Filtering Sebagai Pemberdayaan Masyarakat Usaha Kecil Menengah (UKM) di Pulau Ternate', PROtek: Jurnal Ilmiah Teknik Elektro, 3(1), pp. 20-25.

Busthomy, A. and Sultoni, R. H. (2016) 'Sistem Pendukung Keputusan Untuk Pemilihan Objek Wisata Di Kabupaten Pasuruan Dengan Menggunakan Metode Fuzzy', JIMP-Jurnal Informatika Merdeka Pasuruan, 1(2).

Firmansyah, M. D., Santoso, E. and Dewi, R. K. (2017) 'Sistem Rekomendasi Tempat Wisata di Kota Malang Menggunakan Metode Hybrid Fuzzy-Floyd Warshall', Jurnal Pengembangan Teknologi Informasi dan Ilmu Komputer e-ISSN, 2548, p. 964.

Hayati, N. (2011) 'Metode Hybrid (Content Dan Collaborative Based) Nearest Neighbor Untuk Sistem Rekomendasi Pariwisata'.

Kadir, A. (2008) 'Belajar Database menggunakan MYSQL', Yogyakarta, Andi Offset.

Kusumadewi, S. and Purnomo, H. (2010) 'Aplikasi Logika Fuzzy untuk pendukung keputusan', Yogyakarta: Graha Ilmu, pp. 33-34.

Prawira, J. J. C. Y. and Wardani, T. I. (2018) 'Aplikasi CMS WordPress Untuk Pembuatan Website Sebagai Media Promosi Di Wisata Keramik Dinoyo Kota Malang', Jurnal Aplikasi Bisnis, 3(2), pp. 485-489.

Putra, M. R. P., Jonemaro, E. M. A. and Arwani, I. (2018) 'Penerapan Mechanics Dynamics Aesthetics Framework pada Game Pengenalan Wisata Kota Malang', Jurnal Pengembangan Teknologi Informasi dan Ilmu Komputer e-ISSN, 2548, p. 964.

Welling, L. and Thomson, L. (2003) 'PHP and MySQL Web Development'. Sams Publishing. 